\title{
Not dead yet: The Australian union movement and the defeat of a government
}

\author{
Kathie Muir and David Peetz ${ }^{1}$
}

\begin{abstract}
Australian unions launched the 'Your Rights at Work' campaign to combat the hostile 'WorkChoices' legislation, introduced in an already difficult environment in which union influence had waned significantly. The campaign was central to the defeat of the Howard Government. It was unmatched in Australian political and industrial history due to: its scale and duration; its diversity of activities and technologies; its degree of community support; and its expense. The choice of specific repertoires of contention, the management of protest identities, the increased self-reflexivity of both the movement as a whole and many of the activists within it and the willingness of unions to devote vast resources to the campaign were critical to its success. The willingness of union movement to adapt and innovate around their traditional responses — especially mass protest—and consciously re-package their image underpinned the success. Not all the union movement's goals were achieved, as union membership failed to increase, but the prospects for union survival and growth are much stronger as a result of having defeated WorkChoices.
\end{abstract}

\footnotetext{
${ }^{1}$ Kathie Muir is the author of Worth Fighting For: Inside the Your Rights at Work Campaign (UNSW Press, 2008) which examines the innovative Australian union campaign against anti-worker legislation enacted by the conservative Howard government. She is senior lecturer in the School of Social Sciences at the University of Adelaide.

Contact details: Gender, Work and Social Inquiry, School of Social Sciences, University of Adelaide, SA 5005, Australia; telephone 61-8-83033390; fax 61-8-8303772; kathie.muir@adelaide.edu.au.

David Peetz is professor of employment relations at Griffith University, Brisbane, and author of Brave New Workplace: How Individual Contracts are Changing our Jobs (Allen \& Unwin, 2006) and Unions in a Contrary World: The Future of the Australian Union Movement (Cambridge, 1998).

Contact details: Department of Employment Relations and Human Resources, Griffith University, Nathan, QLD 4111, Australia; d.peetz@griffith.edu.au.
} 


\section{Introduction}

Men in balaclavas, tethered to guard dogs. They wander the docks, under the glare of spotlights late at night, to track down and evict from the premises any union member who still thinks he is employed on the waterfront. For many Australians it is the abiding image of 1998. Trade unionists employed by Patrick Corporation have been sacked across the country - retrenched, it transpires, through a corporate ruse. Their places are taken by non-unionists employed under individual contracts, working for a firm associated with the right-wing National Farmers' Federation. With perfectly coordinated timing, the Howard government the same evening passes a law providing redundancy payments for the sacked unionists. Nationwide, the union movement is on the skids. In just eight years it has lost 620,000 members - almost a quarter of its membership. It faces adversarial employers and antagonistic state and federal governments, all of which have passed hostile legislation within that eight-year period. Now the jewel in its crown - the Maritime Union of Australia (MUA) - is facing the prospect of a humiliating defeat, and probable extinction, at the hands of a determined employer and the most aggressively anti-union government in a century, one which eagerly awaits the union's next move: a national strike to try to shut down ports around the country. The damages bill that the union will be slapped with in court under the new Workplace Relations Act will bankrupt the union. It will be, for Australia, what the miners' strike was for Britain: a defining moment; the symbolic, if not the total, end of union power in Australia.

Nine and a half years later, at the Wentworth Ballroom, Prime Minister Howard appears to tearful Liberal Party faithful on election night, to concede defeat. Indeed, he admits, it looks like he will lose his seat in Parliament. When the image of the woman who will win his seat appears on a large television screen, one of the faithful calls out 'get a facelift, you slag!' But it is the Prime Minister whose face cannot be saved. Nationwide, unionists across the country, many wearing the signature orange t-shirts of the 'Your Rights at Work' campaign, celebrate long through a night that appears anything but dark. Not since 1949 has a single government policy decision so dominated an election campaign. Not in living memory has the union movement played such a crucial role in defeating an incumbent Australian government. 
Something has gone badly wrong with the script. A movement that was supposed to be terminally ill has exerted its power definitively. The man who sought to drive a stake through its heart has instead been impaled on a poll. This chapter tells how the script for the destruction of the union movement was written, how the script was torn up, and how the play is turning out.

\section{The emerging crisis in Australian unionism}

Employers started to move against unions as the economy changed in the 1980s. The new federal Labor government, which had come to office in 1983, embarked on a program of economic reforms that included cuts in tariffs and subsidies, deregulation of financial and other product markets and eventually (following a major crisis of confidence in currency markets and a collapse of the terms of trade in the mid 1980s), privatisation. Although not following the radical neoliberal model of New Zealand's Labour government, in part because it was constrained by its Accord relationship with the Australian Council of Trade Unions (ACTU), it was still an ambitious reform agenda, and employers faced competitive pressure they had not previously encountered. In the mid 1980s there were a series of major industrial disputes in which employers for the first time sued unions under common law, winning substantial damages and the disputes. An almost evangelical neoliberal movement organised principally around the newly formed H.R. Nicholls Society - began lobbying the media, policy makers and business leaders to the cause of radical deregulation of the labour market. Liberal politicians John Howard and Peter Costello - later to become Prime Minister and Treasurer - were early adherents to this cause, and sympathetic policies became embodied in Liberal Party policies at state and federal levels, and in the approach of the Business Council of Australia, representing Australia’s largest corporations. Mainstream employer associations originally resisted radical change but by the early 1990s the major employer body, the Australian Chamber of Commerce and Industry, became a convert.

When the Howard government was elected in 1996, the union movement was already in deep decline. The formal system of arbitration and awards and the informal system of compulsory unionism, under which unions had prospered, had been stripped away 
by labour market reforms at state and federal level in the first half of the decade. At the state level, where conservative governments reigned, legislation had been uniformly adverse for unions, prohibiting closed shops and promoting in various ways non-union forms of bargaining and the weakening or abolition of award safety nets. At the federal level, where Labor was in power, the move from award reliance to enterprise bargaining was accompanied by various provisions designed to maintain the primacy of unions and collective bargaining. Indeed, the ACTU, with the support of most but not all unions, had been one of the principal instigators of the shift to enterprise bargaining.

But most unions were ill prepared for the move away from tribunals. They had developed structures and strategies that reflected the needs of successful engagement with the arbitration system: skilled operatives who could persuasively argue the workers' case to a tribunal, or do a deal with employers that would satisfy everyone. What they lacked was an effective, widespread, activist workplace presence. Of course, in some unions (such as those representing waterfront workers or coal miners) most workplaces were well organised, with active delegates, committees and members, and in most unions there were some workplaces that were well organised. Yet many unionised workplaces across the country were characterised by membership but not activism. This was a strength for unions during the arbitration years, as it maintained efficient centralised control and facilitated effective, coordinated action across industries and occupations. But this state of affairs became a fundamental weakness when the arbitral machinery was largely dismantled, or at least pushed off centre stage, in the early 1990s. Unions that were weakly organised at the workplace level were ripe for the picking when employers questioned the value of continuing to accommodate relations with unions. Members saw little in the way of activist gains by unions with whom their main interaction was a fortnightly dues deduction, and were offered a better deal, or an offer they could not refuse, by their bosses. It was in workplaces with an inactive union presence that the membership losses of the 1990s were concentrated (Peetz, 1998).

Even before coming into office, the Liberals had set about redesigning the workplace laws. The union movement campaigned against it but its efforts were eventually counterproductive, as a result of the 'Cavalcade to Canberra' protest that led to violent 
scenes outside and inside Parliament House, widely shown in the media and discrediting the legitimacy of union claims (Bailey and Iveson 2000). That - and later an alleged ransacking at the office of Johnson Tiles in Victoria in 2001 by a renegade faction of the manufacturing workers union (Fonseca 2001) - led to a slew of negative headlines and widespread political and media condemnation of unions as 'bullies' and 'thugs' (Muir, 2006). By the end of 1996, a new Workplace Relations (WR) Act was in place, laying the ground for a major challenge to union power. The new Act allowed the creation of official individual contracts, known as Australian Workplace Agreements (AWAs). Through these, minimum standards in tribunal-determined awards could be undercut, provided the agreements met a 'no disadvantage test', under which employees must be no worse off overall than under the relevant award. AWAs were to be assessed not by an independent tribunal but by an agency whose major purpose was to promote the use of AWAs. The WR Act also prohibited any remaining compulsory unionism arrangements and introduced substantial opportunities for penalties and damages claims against unions engaged in industrial action other than when negotiating a new enterprise agreement.

Approaching the end of the decade, then, the union movement faced challenges from a new, harsh legislative environment, a government with an ideological commitment to removing union influence from the workplace, an urgent need for internal restructuring and for renewal at the workplace, and a number of prominent employers willing to take up opportunities provided by the new federal regime. Most prominent amongst those employers, at least in terms of column inches of news, was Patrick Corporation, which in combination with the federal government contrived, as we saw, to dismiss its entire unionised workforce. Yet the union, and the ACTU, failed to take the bait that had been laid down. To the chagrin of many involved, instead of calling a national strike on the waterfront, the MUA let work at the other major stevedoring company, $\mathrm{P} \& \mathrm{O}$, continue, while encouraging union and community picketing of the Patrick docks. It launched a court challenge against Patrick, the government and the company associated with the farmers, alleging a conspiracy to breach the freedom of association provisions of the government's own WR Act. Public sympathies in major disputes normally sided strongly with the employer, as Australian unions had a longstanding image problem. This arose from their frequent use of industrial action when the norms of an arbitral-based system were about avoiding strikes. Yet in this case 
public opinion split, with sympathy tending towards the union, due to the nefarious appearance of the sacking and replacement of workers. Public support for the union movement surprised Patrick and the Government, both believing that 'wharfies' were widely regarded as lazy and corrupt. The union won its case in the federal court. The employer and government appealed all the way to the High Court, but despite gaining major concessions on productivity improvements that would have to be made, they could not prevent the High Court from ordering the company to allow the unionists back on site, and to dismiss the replacement workers (Trinca and Davies, 2000; McConville, 2000). Although many MUA members' jobs were lost through the restructuring that followed, the union had won on the core issue of preventing the deunionisation of the docks through a corporate ruse. The waterfront campaign combined legal, political, industrial and community strategies as its most prominent features, making effective use of the free media with very limited paid advertising (one thirty-second television advertisement screened over three days).

As the radical approach adopted by the unions in the waterfront dispute signalled a new strategy for that union, so too the union movement at large was entering a new phase. By the late 1990s the leadership of the ACTU, in particular incoming secretary Greg Combet (also heavily involved in strategising the MUA campaign), recognised that Australian unions needed to fundamentally change the way they operated. In particular, the long standing focus on providing a 'service' to members should be abandoned in favour of an 'organising' approach. Earlier that decade, key unionists had visited the United States, where an 'organising model' was emerging - or rather, re-emerging - in unions that had adapted the principles of organising from successful community activist campaigns. This model was traceable to the work of activist Saul Alinsky, who in turn developed his skills while working as a union organiser in the 1930s Jungle of Chicago slaughterhouses (Alinsky, 1946). In effect, the movement was re-learning from its past.

The key idea behind organising was that union members should be activated to deal with workplace issues for themselves, rather than union officials remotely fixing problems for them. This promoted ownership of problem-solving, of campaigning and of the union itself. It necessitated unions developing, training and supporting workplace delegates. It required major changes in the role and status of organisers and 
other officials. And, most challenging for unions, it required democratisation, so that decisions and actions at the workplace reflected the intentions of members at the workplace. Members could not have power in the workplace if they did not have power in the union. The ACTU was restructured to reallocate resources towards supporting organising and training.

By the time of the 2004 federal election, a number of unions had advanced a significant way towards organising, but often unevenly. Branches within many unions differed substantially in the extent to which they adopted, or at least attempted to adopt, organising principles. Some unions rejected the agenda. Over the first half of the decade, union membership stabilised. The outcome of that election would, however, pose the biggest challenge the union movement had faced - bigger even than the MUA sackings.

\section{WorkChoices}

The Howard Liberal government, re-elected in 2004, unexpectedly gained control of the Senate, with effect from July 2005. With support from employer groups, the government set about rewriting the laws, to introduce changes that had been previously thwarted by the Senate, plus others that it had never previously dared to advocate publicly. Key elements were outlined in Parliament in May 2005. A more detailed account was delivered in October 2005, along with the Orwellian name for the reforms: 'WorkChoices'. Within a month a Bill was introduced into Parliament and less than five weeks later it had passed both chambers, to become law with effect from March 2006.

WorkChoices introduced further restrictions and heavier penalties on unions undertaking industrial action. It imposed major limitations on union officials' right to enter workplaces. It took away many remaining powers of the independent tribunals, transferring some to government agencies. It sought to effectively abolish state jurisdictions, so all employees would come under federal law. Two changes were even more critical. WorkChoices abolished protection against unfair dismissal for all workers in firms with less than 101 employees, and in all cases where employers could claim 'operational reasons' as part of the justification for dismissal. And it abolished the 'no disadvantage test' on agreements, enabling AWAs to undercut 
minimum provisions for penalty rates, overtime pay and other 'protected conditions' without compensation. Once the law came into effect, such reductions became the norm in AWAs, and numerous stories emerged in the media (most strategically released by unions) of workers having pay and conditions cut through AWAs, often in combination with the threat, or actuality, of dismissal.

While accompanied by much of the neoliberal rhetoric of 'choice' and productivity, WorkChoices was anything but market-based. Its 1388 pages of legislation, 414 pages of regulations and 890 pages of explanatory memoranda - 2692 pages in total sought to regulate countless aspects of the employment relationship, in a level of detail not seen in any other developed country. Fines were applicable where agreements contained provisions that offended the federal Minister - for example, provisions for unfair dismissal protections or union training. One corporate lobbyist likened it to the "old Soviet system of command and control, where every economic decision has to go back to some central authority and get ticked off" (quoted in The Age 26 March 2006). By that standard, the laws could not be said to be neoliberal. But if neoliberalism is understood as not being primarily about the operation of unfettered markets, but rather as being about the transfer of power to capital, then WorkChoices would fall unquestionably within this definition.

\section{Unions respond: Your Rights at Work}

Aware that the 2004 election result meant that anti-union legislation was imminent, unions immediately began development of the campaign that came to be known as Your Rights at Work (YRaW). For the next three years the union movement focussed on the repeal of the WorkChoices legislation, which in turn required the defeat of the Howard government. Unions believed only an Australian Labor Party (ALP) government could bring about such change.

The immediate goal of overturning WorkChoices was linked to key long-term goals of movement revitalisation, membership growth and increasing union power, both in ends (the movement could not revitalise under such adverse laws) and in means (the techniques that would be used in YRaW drew on those used as part of the broader shift towards 'organising'). This congruence of long-term and short-term goals, together with the overwhelming threat to workers' rights and union operations, was 
critical in convincing wavering unions of the necessity to devote unparalleled resources to the YRaW campaign, including to an unprecedented expensive TV advertising campaign. The YRaW campaign also seemed likely to progress other long-term goals, broadening alliances with community organisations and demonstrating the critical significance of the union movement to its estranged offspring, the Australian Labor Party.

Unions launched the YRaW campaign in April 2005. It was unmatched in Australian political and industrial history for many reasons: its scale and duration; its diversity of activities and technologies; its degree of community support; and its expense. The YRAW campaign involved the classic tasks of movement production, requiring the re-defining and re-energising of a movement that was excluded by government and widely written off by mainstream media commentators as irrelevant. YRaW can be usefully analysed from a social movement perspective in relation to two of the key modes of analysis outlined in Chapter 1 of this volume. To understand the innovations and successes of YRaW, it is useful to consider the frames employed and the choice and application of the repertoires of contention.

\section{Framing the campaign: 'Rights at work' vital to 'working families'}

The ways in which the issues were framed, the strategic messaging and message discipline and choices regarding television advertising were crucial. It was not sufficient for the ACTU to focus on their existing supporter base, as defeat of WorkChoices required a change of government. The ACTU campaign targeted swinging voters in low and middle-income brackets who had recently voted for the Coalition but who earlier might have aligned with the ALP. These were known in the media as 'Howard’s battlers' (Brett, 2004, pp. 80-81; Scalmer, 1999). The ACTU commissioned extensive market research to ascertain this group's concerns and the ways to frame messaging that would best resonate with its members. As this campaign had to succeed in the highly mediated context of electioneering it required a new approach, one that could re-present the politics of work to appeal to a general audience. Market research and advice of media professionals was far more influential than in any previous union campaign. 
In June 2005, before the legislation had been finalised - indeed before the name 'WorkChoices’ was even chosen - the \$30 million YRaW television advertising (funded by a levy on members) commenced. It was instrumental in framing the public debate on the ACTU's terms. This happened from the time the 'Tracy' advertisement went to air in that month. This ad depicted a mother (Tracy) caught between the needs of her young children, who needed to be looked after, and a boss who demanded on threat of dismissal that she come into work at short notice to work an additional shift. None of the YRaW campaign messages concerned the impact of WorkChoices on unions - they all concerned workers' rights and the needs of working families. This latter theme was also taken up by the ALP and used through its subsequent election campaigning. The Government's version of 'fairness' that it claimed would be advanced by the adoption of WorkChoices was not accepted. Instead the public clearly viewed the WorkChoices legislation as an abuse of power and a betrayal of the great Australian national characteristic the 'fair go'.

The campaign relied on thousands of advocates, and so theories of framing were applied in communicating to the supporter base the importance of being conscious of how they argued against the laws. George Lakoff's (2004) book Don't Think of an Elephant was used to assist members and community supporters to develop a working understanding of the concept of framing and why it was important. Arguments had to be framed to win support of key audience segments who were not existing union members. Research undertaken by Essential Media Communications and AusPoll found the frame of 'rights' resonated most clearly with the target group. People believed they had rights regarding their work and were incensed to think these rights could be taken away. They 'didn't want Australia to become like America', they thought the laws were 'unAustralian', were a breach of the much valued 'fair go', 'would hurt those most vulnerable', and flew in the face of expectations that 'if you work hard, you get ahead'. Furthermore, people believed the government had no mandate for the introduction of the laws and that they were therefore 'undemocratic' (Muir, 2008).

These messages were emphasised in all elements of campaign messaging. They echoed unease about the laws in the public's mind. A reiterative feedback loop was formed whereby responses from the community were reinforced by union leaders and 
ACTU advertising and in turn were the central concerns expressed by the public in shopping centre discussions, at public meetings and through on-going opinion polling. A Morgan Poll in April 2006 found that 57\% of respondents disagreed with WorkChoices and only $20 \%$ agreed. This was an increase of $8 \%$ from the $49 \%$ who disapproved in October 2005 (Roy Morgan Research, 2006).

The Government's justification for the legislation and the benefits they promised it would bring were not believed. Eventually the name 'WorkChoices' was so tainted it was dropped from Government websites explaining the legislation and all Government communications, but by then the phrase was embedded in public consciousness. In May 2007 the Government hurriedly introduced amendments including a 'Fairness Test' in an attempt to allay public concerns, and devoted additional public funds to a renewed advertising blitz. In total, the government spent \$137 million on the WorkChoices campaign, and business spent an additional \$8 million. They failed to persuade a sceptical public.

Television advertisements were critical to establishing the agenda and frame for the campaign in a way that proved very positive for the union movement. Brand recognition was well established before the government got around to rushing out their response to the ACTU's initial ads (which they did in July 2005 through an expensive series of dense print ads that had little impact). Many of the ACTU television advertisementss featured the stories of individual (real and fictional) workers. These had a powerful appeal and viewers strongly identified with these scenarios, particularly with Tracy (the mother in the ad referred to above). It felt so real that some people in focus groups thought they had seen Tracy's story reported on a current affairs show.

The framing of the campaign and reliance on paid television advertising drew upon techniques of mediated campaigning more commonly associated with party political advertising than with the union movement or social movements (Bennett and Entman, 2001). It was a big leap for unions but one that was largely appropriate for the specific issues and context in which the campaign was waged. Clearly these techniques are not available to all social movements given the scale of costs and resources required. But within the suite of YRaW initiatives, the power of individual stories and one-to-one communication stood out as applicable in other contexts. The ongoing commitment of 
ordinary Australian people to the notion of a 'fair go' was also significant and may be relevant for other organisations in framing their own protest messages. It exemplifies the theory of 'sentiment pools' through which movements can link into the concerns of potential participants through 'mobiliz[ing] resonant symbols' (Crossley, 2002, p. 135; Snow et al, 1986).

\section{Repertoires of contention in a mediated campaign environment}

The YRaW campaign was waged across a wide range of arenas including: judicial, legislative, mass communication, virtual communication, mass protest and community actions. It involved both traditional and innovative modes of protest working to challenge the legislation from the most material of levels through to the symbolic. It also deeply damaged the public credibility of the government and reinvested the labour movement with public recognition and credibility.

Both YRaW and the Waterfront Dispute built upon strategies, tactics and modes of protest employed by union and other political and social movements in Australia and internationally. The experience of the Waterfront Dispute informed unions' approach to framing debate over WorkChoices, their decision to commission professional media research and marketing and their emphasis on discipline. Movements are always learning from each other and tailoring protest strategies to suit the needs of new contexts. It is a dynamic process and frequently a highly creative one (Crossley, 2002; Tilly, 1995). YRaW combined standard protest actions and events such as mass rallies, petitions, public forums, messaging to the public and supporters in the form of information leaflets, bumper stickers, badges, email and SMS bulletins, along with rock concerts, family picnics and barbecues and a strong on-line component. Heavy emphasis on paid television advertisements was new to the union movement as was reliance on market research, strategic messaging and framing. The ACTU's campaign committee extended and updated traditional actions with new elements.

The emphasis on mass protest was reduced from previous disputes to becoming just one of many strategies, rather than being a reflex response. On two occasions (15 November 2005 and 30 November 2006) national mass protests were repackaged as National Days of Action with a tightly scripted and stage-managed central rally in Melbourne broadcast through Foxtel's (subscription) Sky Channel to satellite rallies 
in over 300 city and regional locations. These were more like media events than traditional rallies. They included pre-taped testimonies from rank-and-file workers who had suffered under the laws together with messages of support from religious and community leaders, politicians and celebrities, satire and real-time contributions from union leaders. Compered by icons of Australian popular culture, the broadcasts were highly televisual, appealing to mainstream media. Segments were widely replayed on television news bulletins, increasing message exposure. They moderated stereotypes of blue-collar macho unionism towards images better embodied by female workers in the caring industries.

The broadcasts were part of an attempt to modify traditional union responses to threat in light, of the critical need to win broader support. The move to downplay traditional mass protest and the degree to which such rallies were 'managed' by the ACTU caused some dissension within the movement. The desirability of a militant response was hotly debated. Some elements called for a national strike and several blue-collar unions wanted more resources devoted to traditional repertoires. However, the political, historical and cultural context invested particular importance on the strategic portrayal of unionism. The 'thug' unionist stereotype was the perennial favourite of employers and the mass media (GUMG, 1976; Ward, 1995). The ACTU was determined that this campaign would not be derailed by unstrategic or self-indulgent outbursts. Whilst the provocation caused by the legislation was acknowledged as being extreme, it was critical this investment of members' funds not be wasted. An early campaign bulletin specifically cautioned:

Every time a union official is in the media it adds [to] or subtracts from our campaign objectives and core messages. We need discipline and solidarity and we need to talk about employee rights, not just union rights (ACTU, 2005, p. $3)$.

This concern with the performance of protest and the expression of particular protest identities carried over into the local level. Community and union activists were reminded that whilst anger was a legitimate and justifiable response to the WorkChoices laws its expression needed to occur in private and safe situations, not in public. Anger management was strongly emphasised as an essential technique of successful protest. 
Campaign organisers urged union officials, activists and community supporters to focus on the key goals of achieving change in legislation and a change in government. The audience could not be convinced by mass protest and in particular would be alienated by aggressive or violent expressions of anger. This close attention to the performance of specific repertoires of protest and the way it was embodied by individual activists was an extension of previous planning and management. Whilst not entirely a new direction, having also been a concern in the 1998 Maritime Dispute, it was a significant escalation of central control over messaging and message discipline which, despite claims by some advocating more traditional militant repertoires (Bramble, 2008), added to the success of the campaign

One innovation in YRaW was its presentation as a community campaign, one that was being run on behalf of Australian working families rather than just on behalf of trade union members. The relatively low role given to unions and the concerns unions themselves had with the legislation, in contrast to the emphasis on individual workers and working families as victims of WorkChoices, was another matter of debate. Some union officials argued that the opportunity for promoting union values and union identities in a positive manner was missed. They were concerned that the victim role was both disempowering and discouraging (Muir, 2008). But it was presented in this manner because of the target audience for the campaign.

The YRaW campaign extended into several arenas that were new to union campaigning and displayed multiple innovations to traditional repertoires of protest. A stand-alone website (rightsatwork.com.au) was created including discussion boards, online fundraising, online petitions, calls for action, resources for organising, links to activists' stories and photos, and copies of advertisements, speeches and other campaign material. Email and SMS information bulletins and calls to take action were developed with the aim of 'moving people from online activism into offline activism' (Stanley, 2007). Such activities have been developed and refined by social movements in Australia and internationally in the arenas of human rights, environmentalism, animal rights and anti-globalization. The LabourStart site run by Eric Lee was one of the first to effectively send out action alerts in support of trade unionists being persecuted internationally and achieved considerable success in its campaigns (Lee, 1997; Meikle, 2002). Subsequently e-activist organisations such as 
MoveOn and GetUp have developed the online petition and call for action into an art form. However, it was the first time that the ACTU had moved to directing a significant component of its campaign online.

Another element innovative within the Australian context was the establishment of the extensive community campaign, although the desirability of moving in this direction had been flagged in early 2004 after an ACTU study tour of American unions (ACTU, 2004). Twenty-four marginal seats held by coalition members were targeted for a community campaign in the belief that an intensive campaign on the ground amongst union members, working families and those most affected by the WorkChoices legislation would be sufficient to swing these seats to the ALP. Affiliated unions funded employment of a full time coordinator in each seat and their activities were supported by the ACTU and state Trades and Labour Councils. Each coordinator was responsible for building an active local YRaW campaign committee and community alliances and developing a high community profile. Whilst individual unions had been active in a few seats in which they had high membership during previous election campaigns this was the first time such intensive and coordinated effort had gone into an election campaign. Membership of local campaign committees ranged from two to six hundred. In many seats the community campaign mobilised retired and younger people who were not members or not active in unions, thus identifying and training new activists. This approach drew on the successful get-outthe-vote mobilising efforts of US unions but it contained specifically Australian elements. In its most successful manifestations, the community campaign produced high levels of enthusiasm, highly self-aware and sophisticated local campaign actions and generated substantial local interest and attention (Muir, 2008; Ellem et al. 2008).

The choice of specific repertoires of contention, the management of protest identities, the increased self-reflexivity of both the movement as a whole and many of the activists within it and the willingness of unions to devote vast resources to the YRaW campaign were critical to its success.

\section{Conclusions: Outcomes and Lessons}

The YRaW campaign was central to the defeat of the Howard Government.

WorkChoices was recognised as the single issue that contributed most to this outcome 
by the ALP, Liberal and National Party campaign directors (Crowe, 2007; Symonds, 2007; Morris, 2007), and victorious and defeated candidates (Maley, 2007; Priest, 2007; Hughes, 2007; Wallace and Hannon, 2007). Its importance was evident long before the election, as polls consistently showed clear majority opposition to WorkChoices, that Labor's IR policy was preferred over the Coalition's by margins of up to 2 to 1, and industrial relations was the key vote-switching issue (Coorey, 2007; Essential Research, 2007). The Howard government's anti-union scare campaign missed the mark because it was based on an outdated proposition - that Australians feared and loathed unions - when opinion polls had consistently shown Australians becoming more positive towards unions over the past quarter century. The swing against the government was 1.3 to $2 \%$ higher in electorates where local YRaW campaigns had been run (Spies-Butcher and Wilson, 2008). Amongst people who had voted for the Liberal Party in 2004, some 36\% disapproved of WorkChoices and, of those, half switched to Labor or the Greens at the 2007 election. No other issue had such salience in switching votes (McAllister and Clark, 2007).

YRaW was an atypical example of movement campaigning in Australia (and internationally) due to its scale. The successes of this particular campaign lay very much within the ways the ACTU and their affiliates adopted multiple repertoires of contention, both traditional and new to the movement but appropriate to the context. Protest and campaign strategies were adopted that suited local small-scale community campaigns, specific regional areas, state based campaigns and the national campaign. Whereas the majority were targeted at swinging voters with caring responsibilities, earning up to $\$ 60,000$ per annum, other niche audiences such as young people were addressed through on-line campaigns, on-campus activities, engagement with popular media and rock concerts. It was the willingness of the union movement to adapt and innovate around their traditional responses_especially mass protest—and consciously re-package their image that underpinned the success of the campaign. Union leadership recognised the challenge of campaigning in a highly mediated environment and the need to succeed in that realm if it was to communicate successfully to swinging voters. Increasing resources are being devoted by all groups to this aspect of campaigning, although it was a new development for Australian unions (Bennett and Entman, 2001). Devising a framing strategy - of WorkChoices as undemocratic, an abuse of power, harming those most vulnerable in society, and an 
offence to national identity and the fair go - and translating that into powerful advertising was critical to the success of YRaW.

The ACTU was operating in a context in which their opponents were representing unions and unionists as irrelevant, undemocratic, self-interested bullies, opposed to progress. These are clichéd but tenacious stereotypes that the media persist in using to report industrial relations. Strategic decisions about campaign actions had to take account of these challenges in communicating. As Martinez Lucio (2003) argues, taking account of the strategy's historical and cultural context is essential in evaluating union use of campaign strategies. The potential positive outcomes of public protest are enhanced by displays 'that tap into prevailing beliefs about democratic practices' (Taylor and van Dyke, 2004, p. 279). Framing of actions and issues is vital and the ACTU's success in this regard was impressive. The YRaW campaign engaged the Australian public's imagination and indignation and successfully established WorkChoices as the condensing symbol of all that was wrong with the Howard Government: arrogant, out of touch, heartless and governing on behalf of business rather than the people. In this way it is arguable that the union movement created a political opportunity where it had not previously existed, where the government had instead worked hard to shut unions out of the public debate and de-legitimise their contributions.

YRaW demonstrated that even in the face of hostile governments that limit movements' opportunities for political engagement and seek to silence dissent there are ways of engaging the electorate directly to achieve change. Indeed as Crossley (2002, pp. 120-121) argues in relation to the Thatcher period in Britain movements can be galvanised into action in response to the actions of hostile governments. YRaW succeeded in recruiting and mobilising new supporters and activists in the context of the election and demonstrated the degree to which the Australian union movement was able to be flexible, unified and take on and respond to new ideas, especially when faced with dire challenges. Significantly, many of these new activists were recruited from the broader community rather than the ranks of existing members.

Yet despite the success of YRaW in defeating the Howard government, not all the union movement's goals were achieved. The new laws introduced by the new Rudd 
ALP government to replace WorkChoices - principally the Fair Work Act 2009 - did not repeal all of those provisions the unions wished to see repealed, particularly in the areas of union rights of entry to workplaces and the treatment of industrial action. Indeed most of the concessions made by the ALP to the business community were announced before the 2007 election, leaving the unions little room to manoeuvre postelection against a government that demonstrably had a 'mandate; for its policy. Despite YRaW's central role in the election outcome, the ALP government granted few favours to the union movement once in office, treating them in an arms length manner, with no more privileges than any number of business groups. While being recognised as a legitimate interest group was a far cry from their exclusionary treatment at the hands of the Howard government, it was also a far cry from the very close relationship with the Hawke and Keating governments of 1983-1996.

Most importantly, YRaW could not stop the loss of union membership that happened under WorkChoices - around 120,000 members were lost, in trend terms, over three years to August 2007. Employees chose to respond to the fears engendered by WorkChoices by tossing out the government, but not by joining unions. YRaW very successfully built the movement's profile and pool of available activists but not its base membership levels. Loss of membership is, in fact, what normally happens when anti-union legislation is introduced, due for example to restrictions on organising and encouragement of non-union alternatives (for example Freeman and Pelletier, 1990). Unions were hoping, however, that workers would consider their rights at work as not just worth voting for, but also worth joining for.

That said, the prospects for union growth, or at least survival, are much stronger as a result of having defeated WorkChoices than they could ever have been if WorkChoices had remained in place. The union movement continues to face major challenges of renewal and membership growth, to which the YRaW campaign has made a positive contribution, in no small part by enabling the union movement to think about campaigning and strategies in new ways. But the broader task of organising and democratising the movement remains. 


\section{References}

Alinsky, S.D. (1946) Reveille for Radicals (Chicago: University of Chicago Press).

Australian Council of Trade Unions (ACTU) (2004) Next Steps: For Australian Unions, Melbourne (Melbourne: ACTU).

Australian Council of Trade Unions (ACTU) (2005) Union Update No. 2 (Melbourne: ACTU).

Bailey, J. and K. Iveson (2000) 'The Parliaments call them thugs: public space, identity and union protest', Journal of Industrial Relations, 42 (4), pp. 517-534.

Bennett, L.W. \& Entman, R.M. (2001) Mediated politics: an introduction, in L.W. Bennet and R.M. Entman (Eds), Mediated Politics: Communication in the Future of Democracy, pp.1-32 (Cambridge: Cambridge University Press).

Bramble, T. (2008) Trade Unionism in Australia: A History From Flood to Ebb Tide (Port Melbourne: Cambridge University Press).

Brett, J. (2004) The new Liberalism, in R. Manne (Ed.), The Howard Years, pp. 74-93 (Melbourne: Black Inc).

Coorey, P. (2007) On rates, Coalition is still trusted, Sydney Morning Herald, 2 November 2007.

Crossley, N. (2002) Making Sense of Social Movements (Buckingham: Open University Press).

Crowe, D. (2007) WorkChoices does the job for Labor, Australian Financial Review, 26 November 2007.

Ellem, B., Oxenbridge, S. \& Gahan, B. (2008) The Fight of Our Lives: An Evaluation of Unions NSW and the Your Rights at Work Campaign (Sydney: Unions NSW).

Essential Research (2007) National opinion poll: summary report, Melbourne: Essential Research, July.

Fonseca, M. (2001), National code of conduct proposed for unions, The World Today, ABC Radio National, 20 July, www.abc.net.au/worldtoday/stories/s332941.htm

Freeman, R. \& Pelletier, J. (1990) The impact of industrial relations legislation on union density in the UK and Ireland, British Journal of Industrial Relations 28(2), pp. 141-164.

GUMG (Glasgow University Media Group) (1976) Bad News (Glasgow: Routledge). 
Hughes, D. (2007) A tighter hold on the mortgage belt, Australian Financial Review, 26 November 2007.

Lakoff (2004) Don't think of an elephant! : know your values and frame the debate : the essential guide for progressives (White River Junction, Vt. : Chelsea Green Pub. Co., 2004).

Lee, E. (1997) The Labour Movement and the Internet: The New Internationalism (London: Pluto Press).

Maley, P. (2007) 'WorkChoices fear campaign to blame’, Australian, 26 November, 8

Martinez Lucio, Miguel (2003) 'New communication systems and trade union politics: a case study of Spanish trade unions and the role of the internet', Industrial Relations Journal, Vol. 34, No. 4, 334-47.

McAllister, I. \& Clark, J. (2007) Trends in Australian political opinion: Results from the Australian Electoral Study 1989-2007 (Canberra: Australian National University) on-line. Available HTTP: http://assda.anu.edu.au/aestrends.pdf

McConville, C. (2000) The Australian waterfront dispute 1998, Politics and Society, 28(3) pp. 393-412.

Meikle, G. (2002). Future Active: Media Activism and the Internet (Annandale: Pluto Press).

Morris, S. (2007) Small swings, vital losses, Australian Financial Review, 26 November 2007.

Muir, K. (2006) Fairness versus choice: the contested discourses of Australian and UnAustralian values in the industrial relations debate, Cultural Studies Association of Australasia Conference. on-line. Available HTTP:

http://www.unaustralia.com/electronicpdf/Unmuir.pdf

Muir, K. (2008) Worth Fighting For: Inside the Your Rights at Work Campaign (Sydney: UNSW Press).

Muir, K. (2008) Worth Fighting For: Inside the Your Rights at Work Campaign (Sydney: UNSW Press).

Peetz, D. (1998) Unions in a Contrary World: The future of the Australian trade union movement (Cambridge: Cambridge University Press).

Priest, M. (2007) Coal and condoms undermine Kelly, Australian Financial Review, 26 November 2007.

Roy Morgan research (2006) Majorities Of People Disagree With IR Reforms, Think They Will Be Bad For Australia: Finding No 4006. on-line. Available HTTP: http://www.roymorgan.com/news/polls/2006/4006/

Scalmer, S. (1999) The battlers versus the elites: The Australian right's language of 
class, Overland, 154, pp. 9-13.

Snow D.E., Rochford, B., Worden S. \& Benford, R. (1986) Frame alignment processes, micromobilization, and movement participation, American Sociological Review, 51(4), pp. 464-481.

Spies-Butcher, B., \& Wilson, S. (2008) Election 2007: Did the union campaign succeed? Australian Review of Public Affairs May. on-line. Available HTTP: http://www.australianreview.net/digest/2007/05/spies-butcher_wilson.html

Stanley, Jessica. 2007. ACTU On-line Director, interview with Muir.

Symonds, A. (2007) Seachangers riding the coastal wave, Australian Financial Review, 26 November 2007.

Taylor, V. \& van Dyke, N.( 2004) “Get up, Stand up.” Tactical repertoires of social movements, in D.A. Snow, S.A. Soule and H. Kriesi (Eds) The Blackwell Companion to Social Movements, pp. 262-293 (Oxford: Blackwell)

The Age (2006) IR laws like 'Soviet-style command’, 26 March 2006.

Tilly, C. (1995) Contentious repertoires in Great Britain, 1758-1834, in M. Traugott (Ed.) Repertoires and Cycle of Contention, pp.15-42 (Durham: Duke University Press).

Trinca, H. \& Davies, A. (2000) Waterfront: the Battle that Changed Australia, (Sydney: Doubleday)

Wallace, R. \& Hannon, E. (2007) Party's tacky slur on opponent cost me votes, says Lib MP, Australian, 26 November 2007.

Ward, I. (1995) Politics of the Media (South Melbourne: Macmillan). 